\title{
Effectiveness of new sources of resistance against oat powdery mildew identified in A. sterilis
}

\author{
Sylwia Magdalena Okoń ${ }^{1} \cdot$ Tomasz Ociepa ${ }^{1}$
}

Received: 23 March 2018 / Accepted: 29 June 2018/Published online: 9 July 2018

(C) The Author(s) 2018

\begin{abstract}
The assessment of the effectiveness of resistance sources to fungal diseases is a very important issue allowing to determine the possibilities of effective use of new resistance genes in breeding programs. In the present work, the effectiveness of new resistance sources to oat powdery mildew identified in wild A. sterilis species was determined. The level of effectiveness was assessed based on host-pathogen tests. A set of 50 Blumeria graminis $\mathrm{f}$. sp. avenae isolates was selected for these tests, which allowed to analyze the effectiveness in different geographical conditions. The isolates were collected in 2010-2017, which allowed to observe changes in the effectiveness of new resistance sources in recent years. Furthermore, based on the results, we postulated the presence of new resistance genes in A. sterilis genotypes identified as resistant. Two of the seven tested genotypes were characterized by a high level of resistance against the used isolates. Moreover, the patterns of infection indicated that the resistance identified in these genotypes was conditioned by a new powdery mildew resistance.
\end{abstract}

Keywords Blumeria graminis f. sp. avenae $\cdot$ Fungal disease $\cdot$ Oat $\cdot$ Resistance genes

\section{Introduction}

Powdery mildew caused by an obligate biotroph, Blumeria graminis f. sp. avenae, is a common disease of oat in temperate regions of Europe and North America, northwestern Himalayan region and China (Aung et al. 1977; Schwarzbach and Smith 1988; Banyal et al. 2016; Okoń and Ociepa 2017; Xue et al. 2017). Crop losses caused by powdery mildew are significant, with estimates up to $39 \%$ (Lawes and Hayes 1965; Jones 1977; Clifford 1995).

There are a few main ways of controlling the disease in oat. First, the occurrence of powdery mildew can be reduced by the application of fungicides (Martinelli 2004). However, excessive use of fungicides may lead to rapid adaptation of pathogens and insensitivity to the chemicals applied. Furthermore, this method is ecologically undesirable. Nowadays, plant protection methods must be compliant with the assumptions of sustainable agriculture that

Sylwia Magdalena Okoń

sylwia.okon@up.lublin.pl

1 Institute of Plant Genetics, Breeding and Biotechnology, University of Life Sciences in Lublin, Lublin, Poland promote economically profitable, environmentally friendly and accepted in community methods of plant protection. In practice, this means using alternative methods of chemical protection. In accordance with the principles of integrated plant protection, the occurrence of powdery mildew can be reduced by proper agricultural science, crop rotation or sowing of intercultivar or interspecific mixtures (Strzembicka et al. 1998; Gacek 2000; Tratwal and Rosiak 2010). The use of genetically mildew resistant cultivars is the most effective and environmentally safety method to reduce the occurrence of powdery mildew.

The possibility of using resistance genes in breeding programs depends on their effectiveness against the existing pathogen races. To date, 8 powdery mildew resistant genes have been described in oat, but only 4 of them provide the resistance to the current $B$. graminis $\mathrm{f}$. $\mathrm{sp}$. avenae pathotypes (Okoń 2015; Okoń and Ociepa 2017). Okoń and Ociepa (2017) have demonstrated that B. graminis f. sp. avenae population occurring in Poland is constantly changing and new virulent pathotypes can appear. Moreover, the continuous use of the same set of resistant genes often results in the selection of pathotypes 
with the matching virulence genes, resulting in resistance breakdown (Czembor and Czembor 2001).

Therefore, it is necessary to search for new sources of resistance and introduce them to breeding programs. From the breeding point of view, new sources of resistance should be characterized by a high level of effectiveness to pathogen pathotypes occurring in a given area and over a long period of time.

Hence, the aim of present study was the assessment of the effectiveness of new potential sources of resistance to powdery mildew identified previously in A. sterilis genotypes (Okoń et al. 2016).

\section{Materials and methods}

A set of 50 single spore isolates of powdery mildew were used to check effectiveness of 7 different sources of resistance against oat powdery mildew identified in $A$. sterilis accessions. As a control, set of cultivars and lines with known resistance genes were used: Jumbo-Pm1, Mostyn-Pm3, AV1860-Pm4, Am25-Pm5, BrunoPm6, APR122-Pm7 and Fuchs susceptible to powdery mildew. Control plant materials were kindly supplied by Sai L. K. Hsam from the Technical University of Munich, Germany. Populations of Blumeria graminis f. sp. avenae were collected from different regions of Poland in the years 2010-2017 (Fig. 1). Single spore isolates were obtained in laboratory condition from Blumeria graminis f. sp. avenae samples.

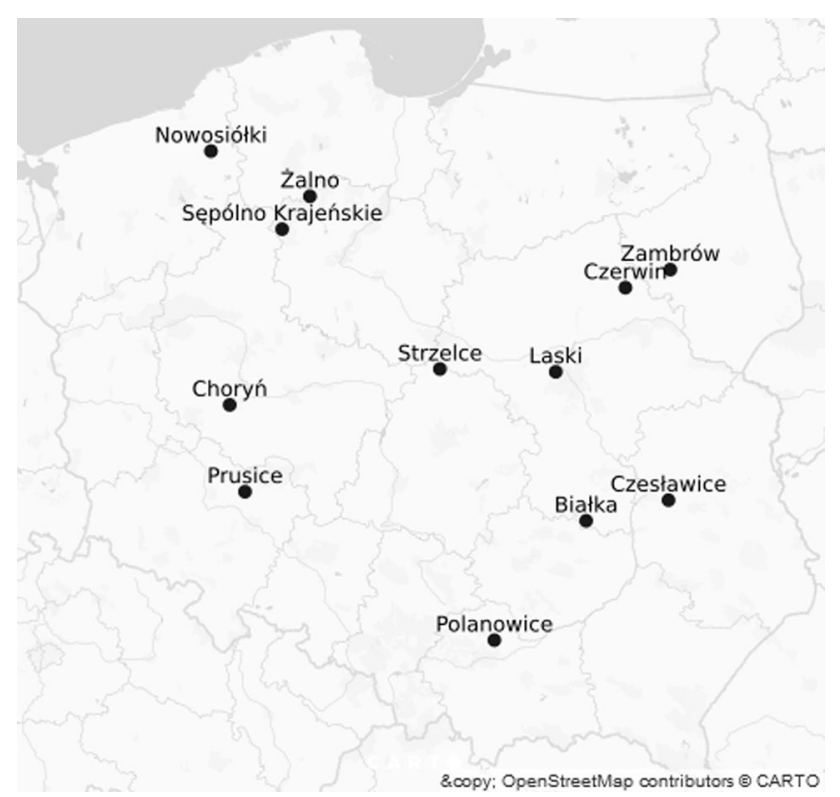

Fig. 1 The geographical distribution of Blumeria graminis f.sp. avenae isolates used in the host-pathogen tests
Host-pathogen tests were carried out according to the method described by Okoń and Kowalczyk (2012). Fragments of leaves were put on agar medium in Petri dishes supplemented with benzimidazole $(6 \mathrm{~g}$ agar per $1 \mathrm{~L}$ of water and $35 \mathrm{mg} / \mathrm{L}$ of benzimidazole) and inoculated with powdery mildew isolates. Disease on the leaves was rated 10 days after inoculation. Reactions to the isolates were grouped into three classes: $R$ (resistant)—from 0 to $20 \%$ leaf area affected relative to Fuchs, $I$ (intermediate) from 20 to $50 \%$ affected and $S$ (susceptible) - greater than $50 \%$ affected.

\section{Results}

Host-pathogen tests were based on isolates collected in the years 2010-2017 in order to evaluate changes in the effectiveness in recent years. Fifty isolates, selected for the effectiveness analysis, were characterized by a diversified infection pattern of control lines and cultivars (Table 1). Comparison of infection patterns of A. sterilis genotypes and control lines allowed to exclude the presence of known and described resistant genes in the tested accessions.

Seven A. sterilis genotypes identified in our previous study (Okoń et al. 2016) as promising sources of resistance to oat powdery mildew were tested to determine their effectiveness. The analyzed genotypes showed varied efficiency levels to $50 \mathrm{~B}$. graminis f. sp. avenae isolates used in host-pathogen tests.

Genotypes PI287211, CN113554 and CN67349 showed the lowest level of resistance to the isolates used in hostpathogen tests. These genotypes were resistant to 23, 22 and 22 isolates, respectively, while they showed a susceptible response to 10,15 and 16 isolates, respectively. For the remaining isolates these genotypes showed an intermediate response (Table 1, Fig. 2). An increasing number of isolates overcame the resistance identified in these genotypes in the years 2015-2017.

Genotypes CN22667 and CN22668 were resistant to 40 and 36 of $50 \mathrm{~B}$. graminis isolates used in host-pathogen tests. A susceptible response was obtained for 6 and 9 isolates, and an intermediate response for 4 and 5 (Table 1, Fig. 2). These A. sterilis genotypes were resistant to all isolates collected in 2010-2013. In 2014-2017, some of $B$. graminis isolates overcame the resistance identified in these genotypes. A changing virulence spectrum in the following years may lower the efficiency of resistances identified in genotypes CN22667 and CN22668.

The highest level of resistance was observed for genotypes CN67383 and CN113536. These genotypes were resistant to 48 and 43 isolates, respectively, while they showed an intermediate response for 2 and 7 isolates, respectively (Table 1, Fig. 2). They exhibited a high level 


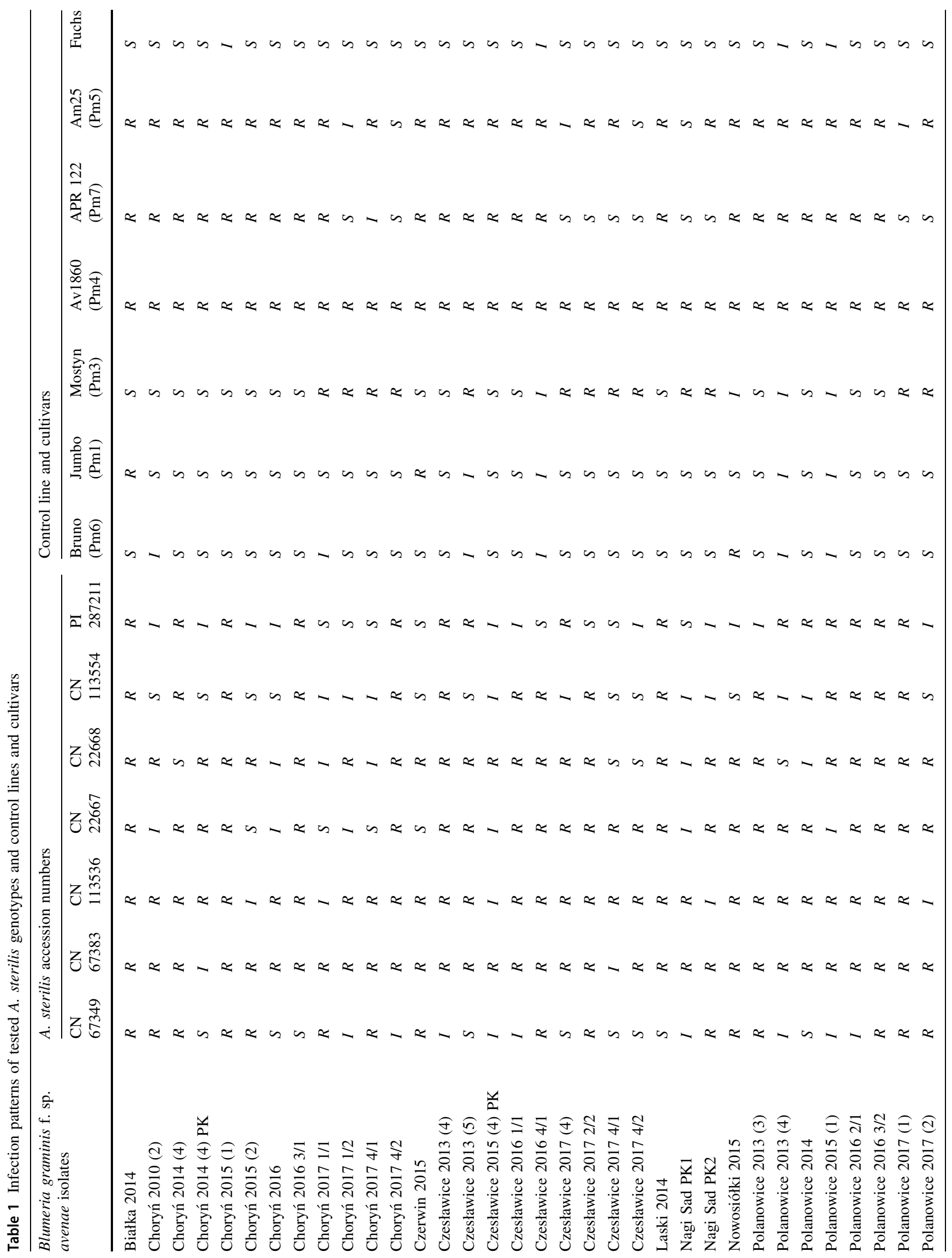




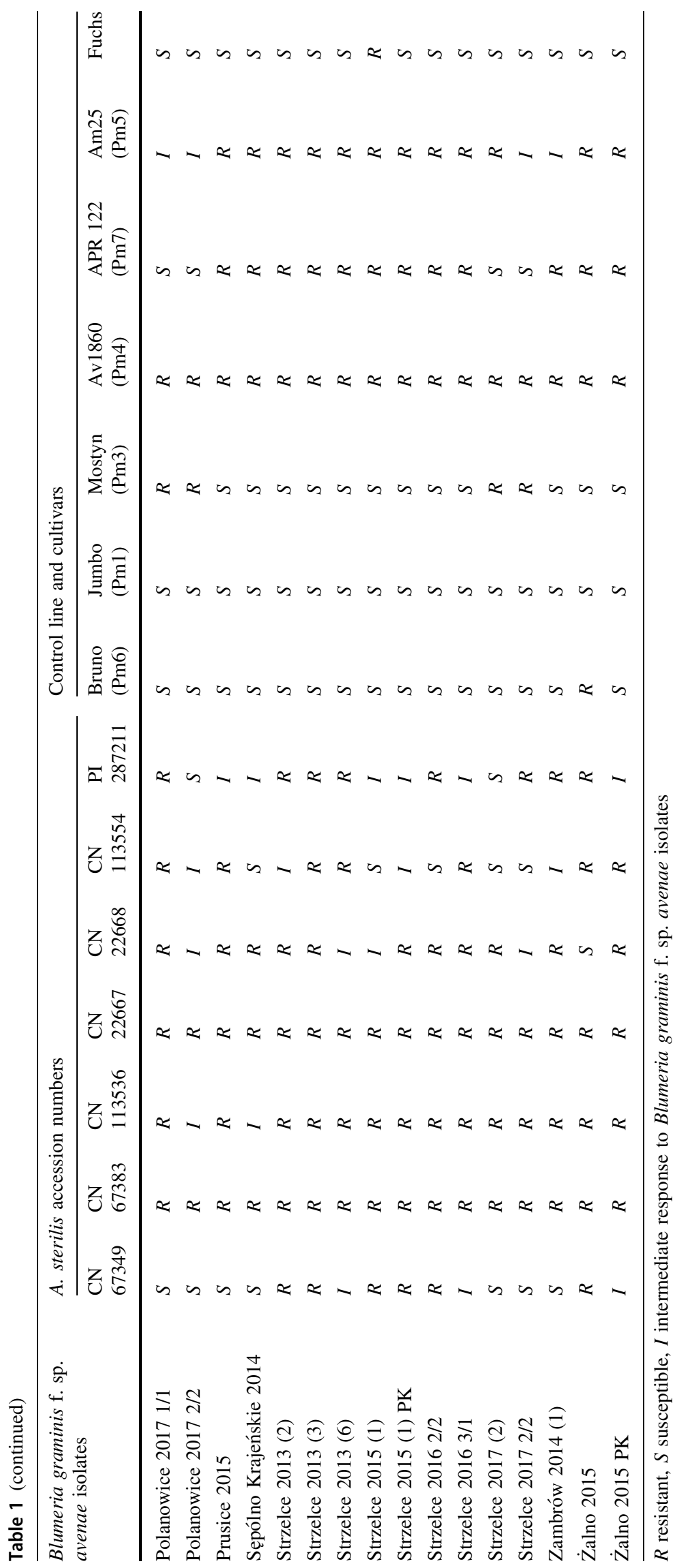


Fig. 2 The response of $A$. sterilis genotypes to Blumeria graminis f. sp. avenae isolates used

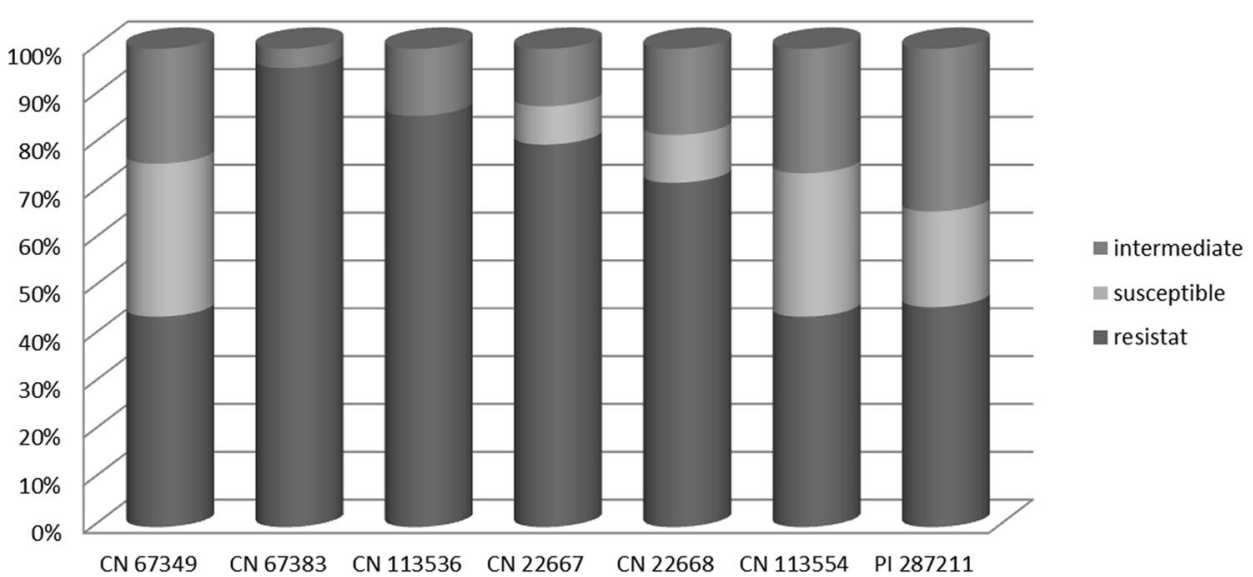

of resistance to all isolates collected in the years 2010-2017. The effectiveness of these resistance sources has not decreased in recent years; thus, we can speculate that it will persist in the coming years.

Based on the obtained results, we can postulate that the resistance identified in A. sterilis genotypes CN67383 and CN113536 is conditioned by not yet characterized resistance genes. These two genotypes can be used as new and effective sources of resistance against powdery mildew in oat.

\section{Discussion}

The identification of new sources of resistance to fungal diseases and their introduction into cultivated crops is a very important element of breeding programs. Selection of only the most effective sources of resistance is a significant factor determining the success of the breeding process (Pietrusińska and Czembor 2015). The resistance of crop plants to pathogens should be genetically diverse, durable, stable over time and effective in various environmental conditions. Therefore, the efficacy of sources of resistance depends on the dynamics of changes in the virulence of pathogen populations. Different levels of powdery mildew pathogen virulence, depending on geographical distribution, was observed by Shi et al. (2009), Xu et al. (2014), Liu et al. (2015), Rsaliyev et al. (2017). Okoń (2015) showed that the effectiveness of powdery mildew resistance genes in oat had changed after introducing isolates from different geographical regions. Okoń and Ociepa (2017) also observed that powdery mildew isolates collected in different parts of Poland overcame the resistance conditioned by the studied powdery mildew resistant genes with varying strength. The current work analyzed the effectiveness of new resistance genes against powdery mildew in oats based on a set of 50 powdery mildew isolates with varied level of virulence, collected in the year
2010-2017 in different geographical regions of Poland. The study underlines that it is necessary to perform tests based on a diverse set of pathogen isolates in order to obtain reliable results on the effectiveness of disease resistance. Observations based on isolates sampled in one region or in 1 year may be insufficient to draw reliable conclusions.

Acknowledgments This work was carried out in the framework of the Programme LEADER V Project Number: LIDER V/21/p325/L-5/13/ NCBR/2014 "Identification of new and effective resistance genes to fungal diseases in oats and development of DNA markers for their identification," supported by the National Research and Development Centre.

\section{Compliance with ethical standards}

Conflict of interest The authors declare that they have no conflict of interests.

Open Access This article is distributed under the terms of the Creative Commons Attribution 4.0 International License (http://creative commons.org/licenses/by/4.0/), which permits unrestricted use, distribution, and reproduction in any medium, provided you give appropriate credit to the original author(s) and the source, provide a link to the Creative Commons license, and indicate if changes were made.

\section{References}

Aung T, Thomas H, Jones IT (1977) The transfer of the gene for mildew resistance from Avena barbata $(4 \times)$ into the cultivated oat $A$. sativa by an induced translocation. Euphytica 26:623-632. https://doi.org/10.1007/BF00021687

Banyal DK, Sood VK, Singh A, Mawar R (2016) Integrated management of oat diseases in north-western Himalaya. Range Manag Agrofor 37:84-87

Clifford BC (1995) Diseases, pest and disorders of oat. In: Welch R (ed) The oat crop. Chapman \& Hall, London, pp 252-278

Czembor HJ, Czembor JH (2001) Resistance to powdery mildew in barley cultivars and breeding lines included in 1998-2000 polish registration trials. Plant Breed Seed Sci 45:21-41 
Gacek ES (2000) Wykorzystanie różnorodności genetycznej roślin w zwalczaniu chorób roślin uprawnych. Post Nauk Rol 5:17-25

Jones IT (1977) The effect on grain yield of adult plant resistance to mildew in oats. Ann Appl Biol 86:267-277. https://doi.org/10. 1111/j.1744-7348.1977.tb01840.x

Lawes DA, Hayes JD (1965) The effect of mildew (Erysiphe graminis f. sp. avenae) on spring oats. Plant Pathol 14:125-128. https:// doi.org/10.1111/j.1365-3059.1965.tb00295.x

Liu N, Liu ZL, Gong G et al (2015) Virulence structure of Blumeria graminis $\mathrm{f}$. sp. tritici and its genetic diversity by ISSR and SRAP profiling analyses. PLoS ONE 10:e0130881. https://doi.org/10. 1371/journal.pone.0130881

Martinelli J (2004) Oat diseases and their control. In: Suttie J, Reynolds S (eds) Fodder oats: a world overview. Food and Agriculture Organization of the United Nations, Rome, pp 197-214

Okoń SM (2015) Effectiveness of resistance genes to powdery mildew in oat. Crop Prot 74:48-50. https://doi.org/10.1016/j. cropro.2015.04.004

Okoń S, Kowalczyk K (2012) Deriving isolates of powdery mildew (Blumeria graminis DC. f. sp. avenae Em. Marchal.) in common oat (Avena sativa L.) and using them to identify selected resistance genes. Acta Agrobot 65:155-160. https://doi.org/10. 5586/aa.2012.069

Okoń SM, Ociepa T (2017) Virulence structure of the Blumeria graminis DC. f. sp. avenae populations occurring in Poland across 2010-2013. Eur J Plant Pathol 149:1-8. https://doi.org/10. 1007/s10658-017-1220-y

Okoń S, Paczos-Grzęda E, Ociepa T et al (2016) Avena sterilis L. Genotypes as a potential source of resistance to oat powdery mildew. Plant Dis 100:2145-2151. https://doi.org/10.1094/ PDIS-11-15-1365-RE

Pietrusińska A, Czembor JH (2015) Gene pyramiding-a tool commonly used in breeding programs breeding programs. Biul Inst Hod I Aklim Roślin 278:3-16

Rsaliyev A, Pahratdinova Z, Rsaliyev S (2017) Characterizing the pathotype structure of barley powdery mildew and effectiveness of resistance genes to this pathogen in Kazakhstan. BMC Plant Biol 17:178. https://doi.org/10.1186/s12870-017-1130-3

Schwarzbach E, Smith IM (1988) Erysiphe graminis DC. In: Smith IM, Dunez J, Lelliot RA et al (eds) European handbook of plant diseases. Blackwell, Oxford, pp 259-261

Shi W, Wang B, Li Q et al (2009) Analysis of the virulent genes of Erysiphe graminis $\mathrm{f}$. sp. tritici and the resistance genes of wheat commercial cultivars in Shaanxi Province. J Triticeae Crop 29:706-711

Strzembicka A, Gacek E, Węgrzyn S, Nadziak J (1998) Powdery mildew intensity, grain yield and its stability of the mixtures of spring wheat cultivars. Plant Breed Seed Sci 42:47-55

Tratwal A, Rosiak A (2010) Fungal diseases occurrence in winter wheat pure stands and mixtures. Prog Plant Prot 50:963-968

Xu Z, Duan X, Zhou Y et al (2014) Population genetic analysis of Blumeria graminis f. sp. tritici in Qinghai Province, China. J Integr Agric 13:1952-1961. https://doi.org/10.1016/S20953119(13)60591-2

Xue LH, Li CJ, Zhao GQ (2017) First report of powdery mildew caused by Blumeria graminis on Avena sativa in China. Plant Dis 101:1954. https://doi.org/10.1094/PDIS-05-17-0678-PDN 